\section{Malcolm McDonald}

is a professor of marketing and Deputy Director of Cranfield School of Management with special responsibility for e-

business. He has extensive

industrial experience, including

a number of years as Marketing

Director of Canada Dry. He is

also Chairman of six

companies and spends much of

his time working with the

operating boards of the world's

biggest multinational

companies, such as IBM,

Xerox, BP and the like, in most countries in the world. He has written 37 books, and many of his papers have been

published. His current interests centre around the use of information technology in advanced marketing processes.

Keywords: marketing, strategy, consultants, practitioners, academics, future
Professor Malcolm McDonald Cranfield School of Management Cranfield University

Cranfield

Bedford

MK43 OAL

UK

Tel: $+44(0) 1234751122$

Fax: +44 (0)1234 752691

\section{Marketing died in the last decade}

\author{
Malcolm McDonald \\ Received (in revised form): 28 June 2003
}

\begin{abstract}
This paper reviews the state of marketing after 50 years of theory and practice. It examines the role of practitioners, consultants and academics and concludes that marketing has been largely relegated to the relatively minor role of promotion and has been sidelined as a contributor to corporate strategy making. The paper then proposes a future agenda for marketing. It proposes a robust model of marketing theory and practice designed to put marketing firmly back at the heart of corporate strategy making.
\end{abstract}

\section{Introduction}

Marketing's current malaise is a symptom of the discipline's deepening disconnectedness from the real world of commerce. It has, in many cases, become less of a beacon and more of a business bolt-on. While factors such as heightened competition, global forces and technological developments have all but redefined the marketing challenge, they have also created unprecedented opportunity for refining marketing techniques and enhancing marketing's contribution to business. So why is marketing so divorced from reality, and what can be done to close the gap?

For one who has spent 16 years as a marketing practitioner and 26 years as an academic, the response to this question is critical. Marketing is the matchmaker between supply and demand: without sound marketing, corporations operate blindly and customers have little hope of finding value-for-money solutions to their problems. Following the white heat of excitement about the future of marketing in the Wills days of the $1960 \mathrm{~s},{ }^{1}$ marketing has today lost its influence in spite of all marketers' best efforts. They need to understand what has gone wrong, and quickly, if they are to recover command and direction.

The purpose of this paper is twofold: to demonstrate marketing's weakening grasp on the vital role it serves in business by providing a brief review of the state of the marketing domain; and to remedy the situation by setting out an alternative model designed to put marketing back at the heart of organisational strategy making.

\section{A brief review of the state of marketing}

'Where is the wisdom we have lost in knowledge?

Where is the knowledge we have lost in information?'

This comment by T. S. Eliot ${ }^{2}$ makes a valid point, which all of us need to take on board if we are not to see marketing as a discipline entirely 
sidelined. ${ }^{3}$ To understand what we have achieved after over 50 years of marketing, let us look at the three main constituencies: practitioners; consultants; and academics.

\section{Corporate success is transitory}

\section{Practitioners}

As for marketing practitioners, what better place to start than with the famous Tom Peters and Robert Waterman book, In Search of Excellence. ${ }^{4}$ According to Richard Pascale,${ }^{5}$ of Peters' original 43 excellent companies, only six were still excellent just eight years later. Tables 1 and 2 confirm that many of Britain's best-performing companies during the decade up to 1990 subsequently collapsed. They also show that during the decade up to 2000, none of the lessons from the previous decade was heeded.

Experience has shown that no company, no matter how powerful, is impervious to change. But rather than waking up to the hard lessons of history and benefiting from preventive and corrective action, firms frequently choose to delude themselves. Table 3 depicts a real company

Table 1: The fates of the UK's top companies, 1979-1989

\begin{tabular}{|llcll|}
\hline Year & \multicolumn{1}{c}{ Company $^{\text {a }}$} & $\begin{array}{c}\text { Market value } \\
(\mathrm{Em})\end{array}$ & $\begin{array}{c}\mathrm{ROI}^{\mathrm{b}} \\
\%\end{array}$ & Subsequent performance \\
\hline 1979 & MFI & 57 & 50 & Collapsed \\
1980 & Lasmo & 134 & 97 & Still profitable \\
1981 & Bejam & 79 & 34 & Acquired \\
1982 & Racal & 940 & 36 & Still profitable \\
1983 & Polly Peck & 128 & 79 & Collapsed \\
1984 & Atlantic Computers & 151 & 36 & Collapsed \\
1985 & BSR & 197 & 32 & Still profitable \\
1986 & Jaguar & 819 & 60 & Acquired \\
1987 & Amstrad & 987 & 89 & Still profitable \\
1888 & Body Shop & 225 & 89 & Still profitable \\
1989 & Blue Arrow & 653 & 135 & Collapsed \\
\hline
\end{tabular}

${ }^{a}$ Where a company has been top for more than one year, the next-best company has been chosen in the subsequent year, eg Polly Peck was rated top in 1983, 1984 and 1985.

b Pre-tax profit as a percentage of investment capital.

Source: Professor Peter Doyle, Warwick University

Table 2: The fates of the UK's top companies, 1990-2000

\begin{tabular}{|llrll|}
\hline Year & \multicolumn{1}{c}{ Company $^{\mathrm{a}}$} & $\begin{array}{c}\text { Market value } \\
(£ b n)^{\mathrm{b}}\end{array}$ & $\begin{array}{c}\text { ROI }^{\mathrm{c}} \\
\%\end{array}$ & \multicolumn{1}{c|}{$\begin{array}{c}\text { Subsequent } \\
\text { performance }\end{array}$} \\
\hline 1990 & Maxwell Communications plc & 1.0 & 5 & Collapsed \\
1991 & Imperial Chemical Industries plc & 8.6 & 13 & Collapsed \\
1992 & Wellcome plc & 8.3 & 40 & Acquired \\
1993 & ASDA Group & 1.6 & 7 & Acquired \\
1994 & TSB Group plc & 3.7 & 20 & Acquired \\
1995 & British Telecommunications plc & 22.2 & 17 & Not profitable \\
1996 & British Steel plc & 3.3 & 19 & Collapsed \\
1987 & British Airways plc & 6.1 & 7 & Not profitable \\
1998 & National Westminster Bank plc & 19.6 & 14 & Acquired \\
1999 & Marconi plc & 29.8 & 22 & Acquired \\
2000 & Marks \& Spencer plc & 5.3 & 7 & Not profitable \\
\hline
\end{tabular}

a Each company was a FTSE100 when selected.

${ }^{b}$ Market values as of 31 December of each year.

c Pre-tax profit as a percentage of equity and long-term debt.

Source: Professor Malcolm McDonald 


\section{Non-reportable marketing items provide the clue to long-term success}

Table 3: Intertech's five-year performance

\begin{tabular}{|lcrrrrr|}
\hline Performance $(£ \mathrm{~m})$ & Base year & 1 & 2 & 3 & 4 & 5 \\
\hline Sales revenue & $£ 254$ & $£ 293$ & $£ 387$ & $£ 387$ & $£ 431$ & $£ 454$ \\
- Cost of goods sold & 135 & 152 & 201 & 210 & 224 & 236 \\
Gross contribution & $£ 119$ & $£ 141$ & $£ 151$ & $£ 186$ & $£ 207$ & $£ 218$ \\
- Manufacturing overhead & 48 & 58 & 63 & 82 & 90 & 95 \\
- Marketing and sales & 18 & 23 & 24 & 26 & 27 & 28 \\
- Research and development & 22 & 23 & 23 & 25 & 24 & 24 \\
Net profit & $£ 16$ & $£ 22$ & $£ 26$ & $£ 37$ & $£ 50$ & $£ 55$ \\
Return on sales (\%) & 6.3 & 7.5 & 8.2 & 9.6 & 11.6 & 12.1 \\
Assets & $£ 141$ & $£ 162$ & $£ 167$ & $£ 194$ & $£ 205$ & $£ 206$ \\
Assets (\% of sales) & 56 & 55 & 53 & 50 & 48 & 45 \\
Returns on assets (\%) & 11.3 & 13.5 & 15.6 & 19.1 & 24.4 & 26.7 \\
\hline
\end{tabular}

Source: The Marketing Process Company

(disguised here as 'InterTech') which apparently has performed extremely well over a five-year period. Table 4, however, reveals that its performance is extremely poor when set in a market context.

Tables 5 and $6^{6}$ also illustrate how one apparently high-performing company is actually in a bad way when the kind of non-reportable items shown in the tables are taken into account.

Getting the whole picture is crucial, though more often than not 'the

Table 4: InterTech's five-year market-based performance

\begin{tabular}{|lcccccc|}
\hline Performance (\%) & Base year & 1 & 2 & 3 & 4 & 5 \\
\hline Market growth & 18.3 & 23.4 & 17.6 & 34.4 & 24.0 & 17.9 \\
InterTech sales growth & 12.8 & 17.4 & 11.2 & 27.1 & 16.5 & 10.9 \\
Market share & 20.3 & 19.1 & 184 & 17.1 & 16.3 & 14.9 \\
Customer retention & 88.2 & 87.1 & 85.0 & 82.2 & 80.9 & 80.0 \\
New customers & 11.7 & 12.9 & 14.9 & 24.1 & 22.5 & 29.5 \\
Dissatisfied customers & 13.6 & 14.3 & 16.1 & 17.3 & 18.9 & 19.6 \\
Relative product quality & +10 & +8 & +5 & +3 & +1 & 0 \\
Relative service quality & +0 & +0 & -20 & -3 & -5 & -8 \\
Relative new product sales & +8 & +8 & +7 & +5 & +1 & -4 \\
\hline
\end{tabular}

Source: The Marketing Process Company

Table 5: Quality of profits

\begin{tabular}{|c|c|c|}
\hline & Virtuous plc (\%) & Dissembler plc (\%) \\
\hline Sales revenue & 100 & 100 \\
\hline Cost of goods sold & 43 & 61 \\
\hline Profit margin & 57 & 39 \\
\hline Advertising & 11 & 3 \\
\hline R\&D & 5 & - \\
\hline Capital investment & 7 & 2 \\
\hline Investment ratio & 23 & 5 \\
\hline Operating expenses & 20 & 20 \\
\hline Operating profit & 14 & 14 \\
\hline Key trends $\rightarrow$ & $\begin{array}{l}\text { - Past five-year revenue growth } 10 \% \text { pa } \\
\text { - Heavy advertising investment in new/improved } \\
\text { products } \\
\text { - Premium priced products, new plant, so low cost } \\
\text { of goods sold }\end{array}$ & $\begin{array}{l}\text { - Flat revenue, declining volume } \\
\text { - No recent product innovation, little advertising } \\
\text { - Discounted pricing, so high cost of goods sold }\end{array}$ \\
\hline
\end{tabular}


Table 6: The make-up of 14 per cent operating profits

\begin{tabular}{|lcc|}
\hline Factor & Virtuous plc (\%) & Dissembler plc (\%) \\
\hline $\begin{array}{l}\text { Profit on existing products over three } \\
\quad \text { years old }\end{array}$ & 21 & 15 \\
$\begin{array}{l}\text { Losses on products recently launched } \\
\text { or in development } \\
\text { Total operating profits }\end{array}$ & $(7)$ & $11)$ \\
\hline
\end{tabular}

\section{The secret of successful marketing is measuring the right things}

devil is in the detail'. Table 7 identifies the defection rate of a real company by segment, while Figure 1 (from a Cranfield University database of leading European companies using an anonymous audience response system) highlights the sad truth that, almost ten years after the famous Reichheld and Sasser article linked customer retention and profitability, ${ }^{7}$ very few companies measure customer retention by segment.

The secret of successful marketing is using the right measures and measuring the right things. A simple enough rule of thumb, but one which is regularly ignored. Figures 2 and 3 (also from a Cranfield University database of over 500 leading European companies over a five-year period)

Table 7: Measurement of segment profitability

\begin{tabular}{|c|c|c|c|c|c|c|c|}
\hline & Total market & Segment 1 & Segment 2 & Segment 3 & Segment 4 & Segment 5 & Segment 6 \\
\hline $\begin{array}{l}\% \text { of market represented by } \\
\text { segment }\end{array}$ & 100.0 & 14.8 & 9.5 & 27.1 & 18.8 & 18.8 & 11.0 \\
\hline $\begin{array}{l}\% \text { of all profits in total market } \\
\text { produced by segment }\end{array}$ & 100.0 & 7.1 & 4.9 & 14.7 & 21.8 & 28.5 & 23.0 \\
\hline $\begin{array}{l}\text { Ratio of profit produced by } \\
\text { segment to weight of segment } \\
\text { in total population }\end{array}$ & 1.00 & 0.48 & 0.52 & 0.54 & 1.16 & 1.52 & 2.09 \\
\hline Defection rate $(\%)$ & 23 & 20 & 17 & 15 & 28 & 30 & 35 \\
\hline
\end{tabular}

Source: Cranfield Database: Payne, A. (1999)

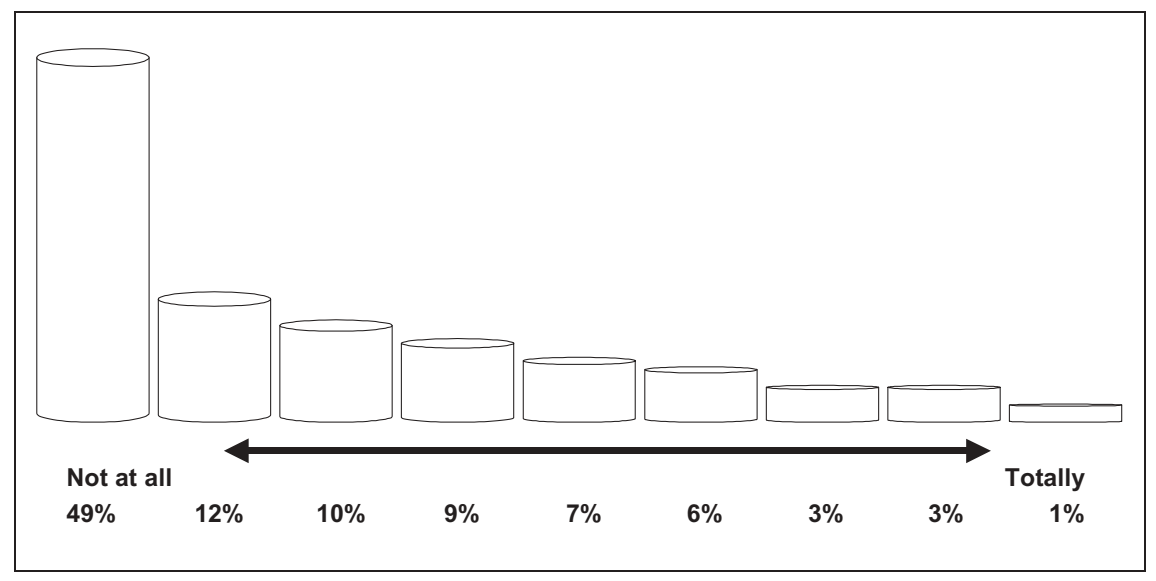

Figure 1: Measure of customer retention by market segment

Source: Marketing Value Added Cranfield Conference, April 2002 
To what extent do you allocate attributable costs (interface costs) to individual accounts (not marmalading costs across the whole customer base)?

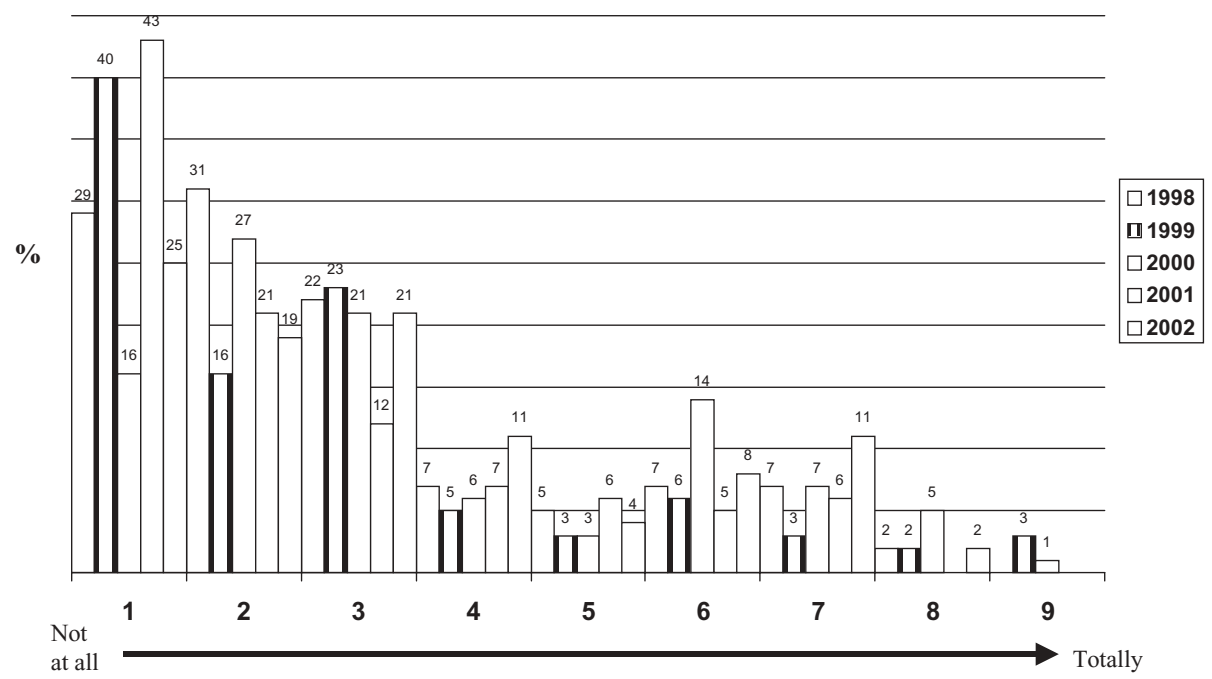

Figure 2: Cost allocation across individual accounts

Source: Cranfield Key Account Management Research Club, 2002

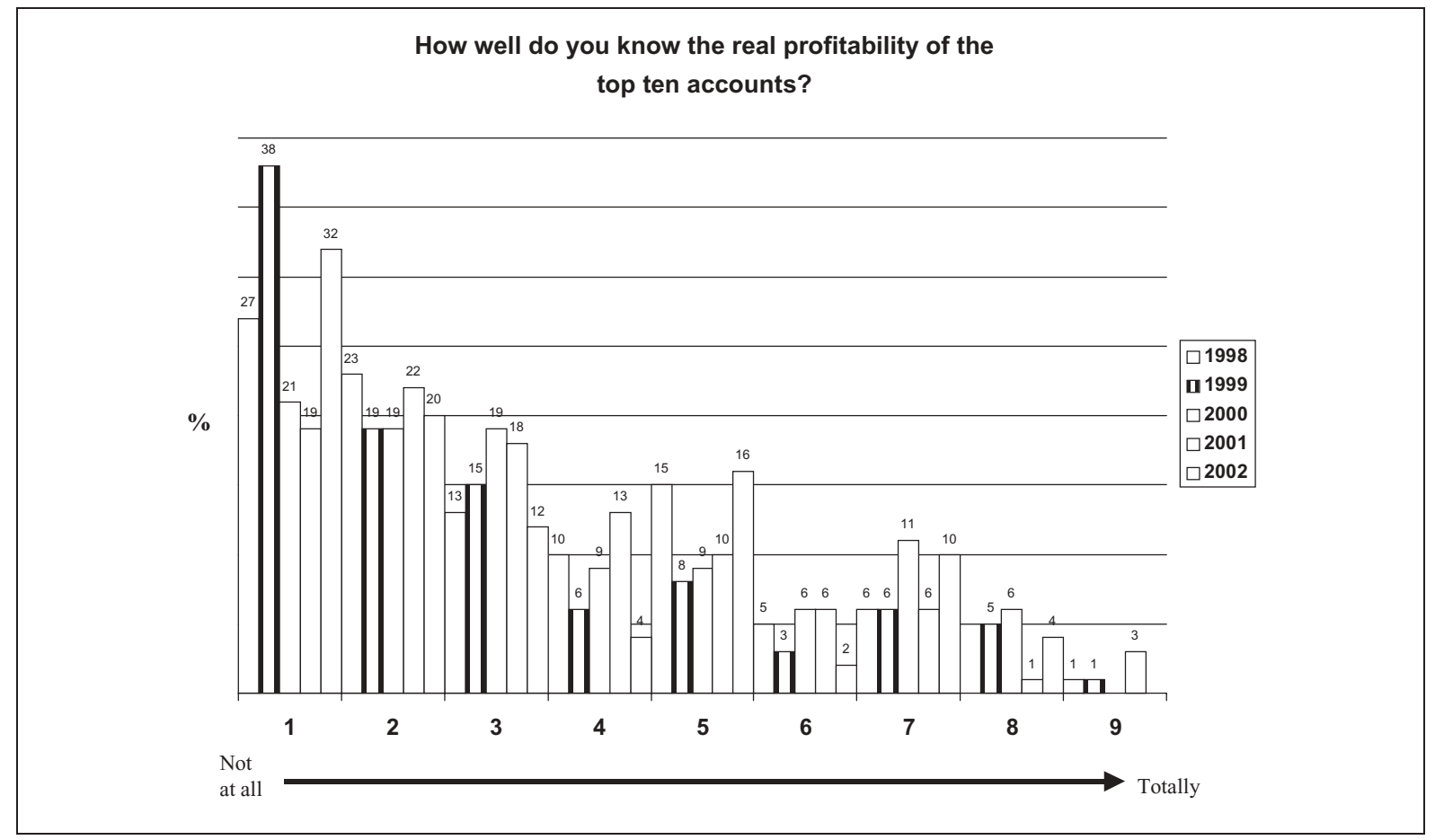

Figure 3: Knowledge of key account profitability

Source: Cranfield Key Account Management Research Club, 2002 


\section{The financial investment} community needs market information to be disclosed in order to make more informed decisions

\author{
The use of tried and \\ tested marketing \\ tools and techniques \\ is disappointingly \\ low
}

show clearly that very few organisations measure market or customer profitability, in spite of the fact that it always has been the cost of dealing with customers after the 'product' leaves the 'factory' that determines profitability.

The importance of relative, comprehensive and transparent reporting is not confined to internal management; meaningful disclosures can impact on the involvement of other stakeholders as well. Figure $4^{8}$ indicates what marketing information the financial community needs to make sensible investment decisions. It also demonstrates that very little of this information is reported in annual accounts.

All relationships require a certain degree of trust, responsibility and accountability, and those within marketing are no different. In 1992, Johnson and Bailey9 developed the 'cultural web' as a method for measuring corporate culture. Figure $5^{10}$ is from yet another Cranfield database which, using the cultural web methodology, captures the attitudes of senior non-marketing managers to marketing practitioners. A cursory glance at the central paradigm, which characterises marketers as 'unaccountable, untouchable, expensive and slippery', leaves us in little doubt about the current status of marketing practice.

Turning briefly to the body of marketing knowledge that has been taught for over 50 years, Greenley's ${ }^{11}$ summary of research into the extent to which it is used (see Table 8) presents a disappointing picture, while Table 9 shows the author's observations on the weaknesses of over 200 marketing plans formally reviewed over a ten-year period.

The new competitive paradigm, in contrast to the conventional 'transactional' model, suggests that in today's challenging global markets the route to sustainable advantage increasingly lies in managing the complex web of relationships that link together partners in a mutually

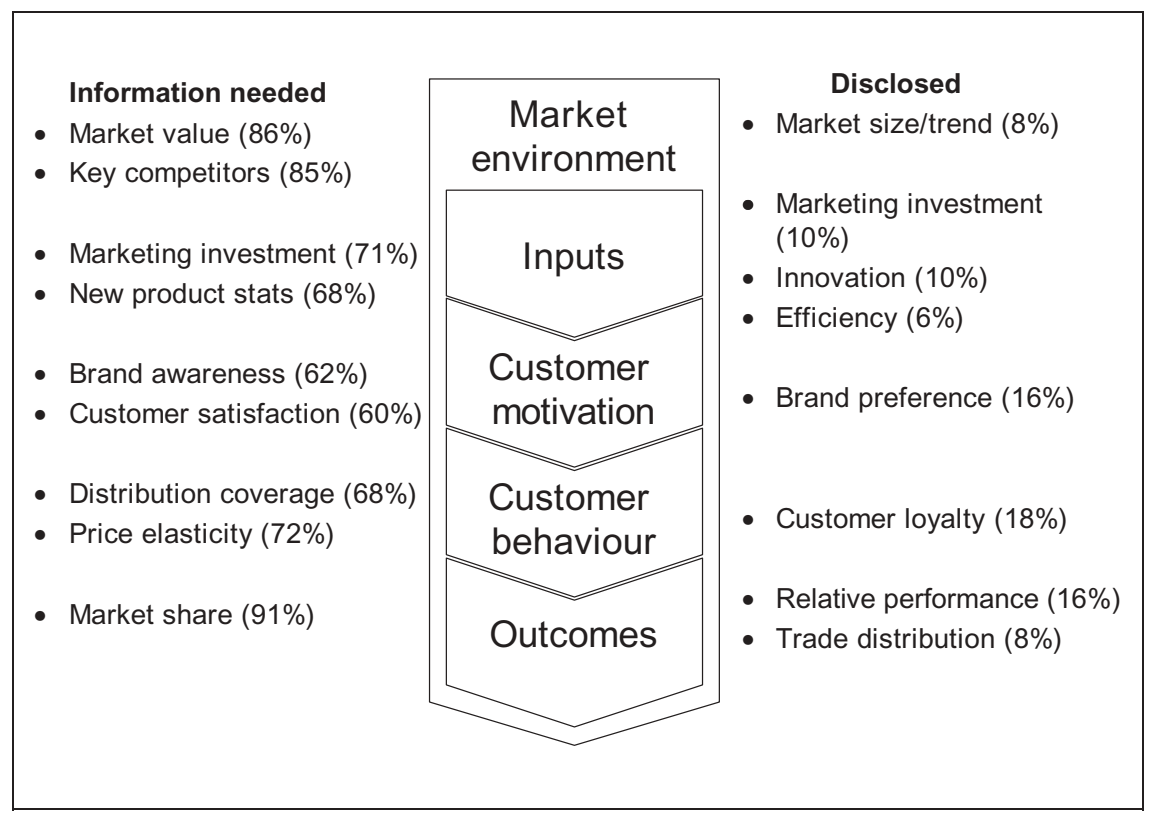

Figure 4: External investor marketing disclosure 


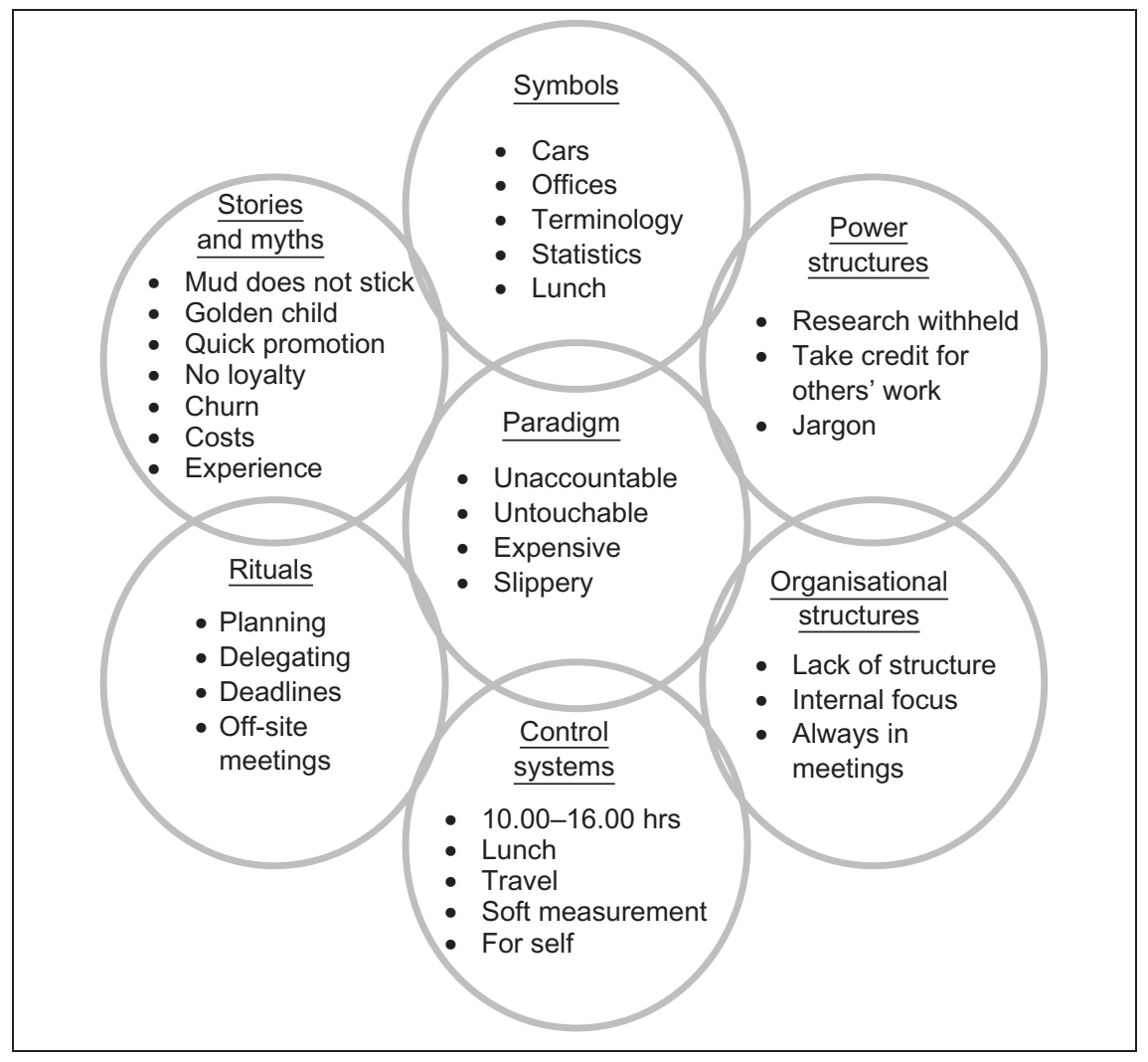

Figure 5: The cultural web — what senior non-marketers believe about marketers

Table 8: Outline of previous research

\begin{tabular}{|c|c|c|c|}
\hline Study & Country & Focus & Outline of results \\
\hline Buzzell and Wiersema (1981) & USA & SP & Limited use of formal planning methods \\
\hline McColl-Kennedy et al. (1989) & Australia & MP & Awareness and usage of methods - low \\
\hline Greenley (1985) & UK & MP & Only $24 \%$ use portfolio analysis; half use PLC analysis \\
\hline Haspeslagh (1982) & USA & SP & Only $45 \%$ use portfolio analysis regularly \\
\hline Hopkins (1981) & USA & MP & A quarter use portfolio analysis, only $13 \%$ use PLC analysis \\
\hline Hooley et al. (1984) & UK & MP & $\begin{array}{l}\text { Half use SWOT analysis, one-third use PLC, only a few use } \\
\text { portfolio, PIMS, perceptual mapping and conjoint analysis }\end{array}$ \\
\hline Reid and Hinkley (1989) & UK/Hong Kong & SP & Little awareness of portfolio and PLC analysis, and PIMS \\
\hline Ross and Silverplatt (1987) & USA & SP & $\begin{array}{l}\text { Half use portfolio analysis regularly, and a quarter use PIMS } \\
\text { regularly }\end{array}$ \\
\hline Verhage and Waarts (1988) & Netherlands & MP & $\begin{array}{l}15 \% \text { use portfolio analysis, } 27 \% \text { use PLC with } 62 \% \text { using } \\
\text { SWOT }\end{array}$ \\
\hline Wittink and Cattin (1989) & USA & MP & Limited use of conjoint analysis by MR consultants \\
\hline Wood and LaForge (1986) & USA & SP & Portfolio analysis used by $67 \%$ of sample \\
\hline
\end{tabular}

$\mathrm{MP}=$ marketing planning; $\mathrm{SP}=$ strategic planning

profitable 'value chain' or 'value network'. Effective marketing planning is essential in balancing customer and commercial interests. Although firms need to be in tune with their markets, customers and competitors, an excessive focus on external matters can distract from the achievement of the returns required for long-term business survival. Marketing managers must therefore have an appreciation of such areas as resource availability, cost generation and organisational capability, as well as an in-depth 
Table 9: Key areas for improvements in strategic marketing plans

- Market overviews contain substantially more information than is necessary, with no hint of the implications for marketing activity.

- Key segments are rarely identified. 'Segments' are often sectors or products, rather than groups of customers with similar needs.

- The competitive situation is not well analysed and plans appear to assume no activity or reaction by competitors.

- SWOT analyses rarely pin down convincingly the value that is required by segments. They are frequently too general to lead to any actionable propositions.

- One's own distinctive competences are rarely isolated and built on.

- SWOTs are rarely summarised clearly and logically in a portfolio which provides a categorisation of the relative potential of each and one's relative strengths in each.

- Marketing objectives are frequently confused with marketing strategies and do not follow logically from the portfolio summary.

- The resource implications of effecting the marketing plans are not always clear.

Source: Based on formal critiques of strategic marketing plans from the SBUs of multinational, industrial and service businesses, McDonald, M., Cranfield Database, May 1996

\section{Marketing practitioners know little about the financial impact of marketing expenditure}

knowledge of customer wants and purchase behaviour. Without the former, it becomes difficult to gauge the attractiveness of different marketing opportunities; without the latter, the business is unfocused.

Figure 6, also from a Cranfield University database, reveals a depressing honesty among senior marketing practitioners about their lack of knowledge about the financial impact of marketing expenditure.

In short, notwithstanding that the above represents a somewhat random and biased selection of examples of the state of practitioner marketing, most readers will, in their heart of hearts, recognise that they are not far from the truth.

\section{Consultants}

Marketing consultants, which include the likes of advertising agencies, appear to have added little. During the past ten years, many companies have sought to reverse their declining fortunes by retreating into faddism, hungrily adopting one craze after another as they were peddled by eager

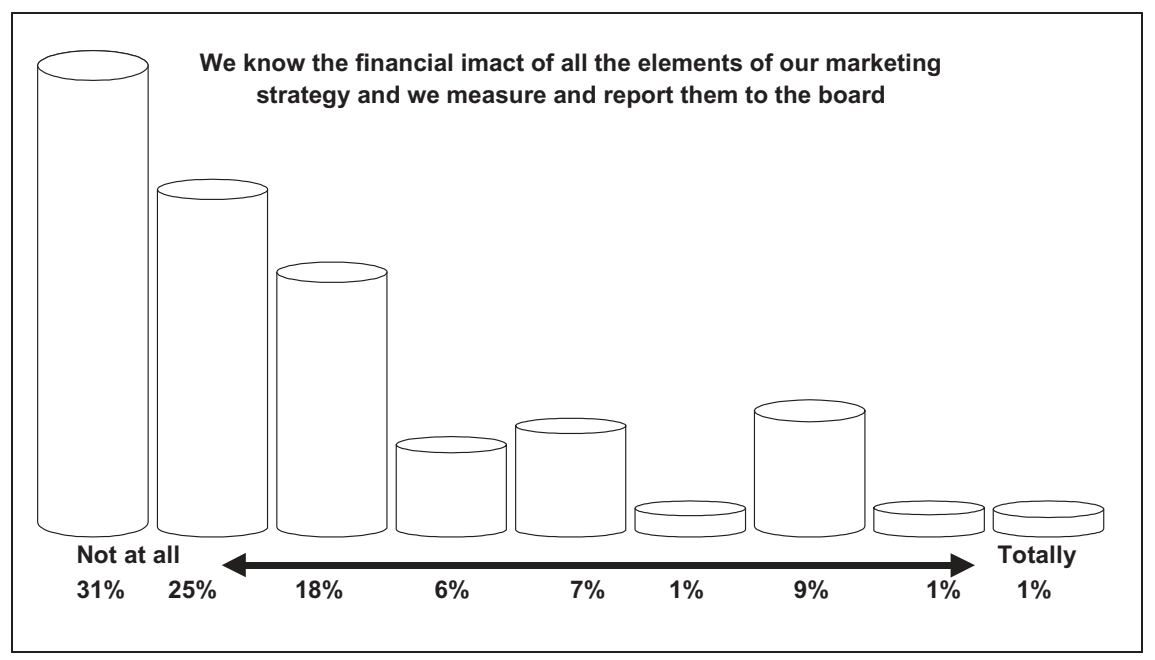

Figure 6: Knowledge of the financial impact of marketing expenditure Source: Cranfield Marketing Value Added Research Club, April 2002 


\section{Fads used as quick fixes don't work}

consultants. In most cases these initiatives have failed because organisations have sought a quick fix without addressing the underlying problems. The author has painstakingly listed over 300 consultant fads developed during the past 30 years, a small selection of which would include: 'In search of excellence', 'Marketing warfare', 'One minute manager', 'Management by walking around', 'Skunk works' and McKinsey's '7Ss'.

The International Standards Organisation's ISO 9000 quality initiative, for example, very laudable when used sensibly, has, in the main, only been a guarantee that organisations can produce rubbish perfectly and consistently. The word 'rubbish' is used judiciously, because there is little point in producing perfectly something that people do not buy. The fashionable trend of business process re-engineering (BPR) has been successful where companies have used it to redesign their processes to create value for customers. For those organisations that have not grasped the nettle of customer satisfaction, it has achieved merely cosmetic productivity improvements. ${ }^{12}$ Balanced scorecards have also been the vogue. BAA, for instance, has used the strategy with great success in managing its complex web of stakeholder relationships. But for those CEOs who do not understand the importance of being market driven, it has proved to be just another fad.

Of course, all of these ideas are fabulous and do work, but only when they are applied in the context of providing superior customer value as a means of providing superior shareholder value. Alas, even in organisations committed to 'relationships' and 'one-to-one' marketing, customers tend to remain the Cinderellas. As Fournier et al. have pointed out, ${ }^{13}$ the rapid development of relationship-building techniques in the USA has been accompanied by growing customer dissatisfaction, as forging intimate customer relationships has often meant abusing rather than delighting customers.

The problem is that companies have become so internally focused they have got carried away with supply-side issues and taken their eye off the customer ball. Until organisations make a serious effort to lift their heads above the parapet and understand their markets and their customers better, all the great initiatives referred to above will amount to expensive, time-consuming mistakes. Most boards are spending too much of their valuable time on internal operational efficiency (doing things right) at the expense of external operational effectiveness (doing the right things).

In conclusion, while consultants have not surprisingly fared somewhat better than the marketing practitioner community, they could hardly be adjudged to have advanced marketing best practice.

\section{Academics}

Finally, of course, there are marketing academics. Table $10^{14}$ lists a small selection of quotations from well-known academics. Most damning of all is the last one. At the Academy of Marketing debate in the summer of 2000 , the author carefully prepared his debate-winning proposal that the academic marketing community was out of touch with marketing practice. One of the supporting facts given was the number of academic 
Table 10: Academics' quotations

- 'Much research is directed at technical refinement, which produces low-risk, quick-win publications that are largely irrelevant or incomprehensible to practitioners. The voice of academics is becoming weaker.' (Hugh Wilmott of MBS)

- Robin Wensley said that marketing academics have had little impact.

'A much wider understanding of the nature of the competitive marketplace is required, given that it is such a central phenomenon.'

- Of ten issues (confirmed by three academic papers and the MSI), only four per cent were addressed in the top five-star-rated academic journals.

\section{The academic community has been encouraged by the RAE to behave in a way which is irrelevant to practitioners}

papers to address the top ten issues of concern to practitioners ${ }^{15}$ in the two foremost five-star-rated academic journals. Four per cent was the derisory number! One wonders whether there is a grain of truth in the assertion that academics are being increasingly forced by the British research assessment exercise (RAE) to write for a narrow, esoteric audience in media that are of little relevance to the real world.

While such journals have relevance to academics and while their role is fully appreciated, the influence and prestige afforded to them by the RAE is out of all proportion to the problems facing the global marketing community and only succeeds in diverting the abundant genius in the academic community into a cul-de-sac. Furthermore, the style of such pieces is also becoming increasingly dense and impenetrable. The author's spoof piece quoted below is a somewhat lighthearted parody of what senior academics face when reviewing certain papers for doubleblind refereed journals.

'In undertaking an in-depth perusal of the evolutionary interaction of this acronymic organisational communication, the dual orientation for the analysis paradoxically required an unashamed repositioning of the eclectic conceptual framework amongst the multidisciplinary body of illuminative speculation in predominantly scholarly bureaucratisation.

Yet, coincidentally, its empirical complexity had to remain relevant to the esoteric realities of postmodern professorial integrative antecedent development trends at appropriately conceptualised and operationally implemented meta levels.

Consequently, it was necessary to review the independently formulated psychometric traditions and to employ confidently the articulatedly present phenomenological methodologies currently available for polysyllabic paradigm exploration. Unfortunately, the ensuing generalised multifaceted model for evaluation (in its specific systems dimension, naturally) had unexpectedly and unexplainably exploded — though not exhaustively. The major administrative atomistic components, suitably enumerated, are now, unfortunately, somewhat hindering the assessor's understanding process.

However, tabulation analysis of the topography implicitly indicates that comprehensive evaluation of the interdenominational micro data has finally exhausted the course assessor and any further critical, 


\section{Marketers must begin to act with deliberate and determined resolve}

\section{Marketing is a professional function, just like finance}

unbiased, postmodernistical review will just have to wait until he has had a few strong gin and tonics!

I suspect you may not know what this means, but I don't really care, even if it takes you half an hour to decode it!

I call this style "anorexia doctoratitis" — an excessive desire to be more and more impressive verbally, leading to mental emaciation and eventually death.' 16

The net impact of this sad neglect by the academic and practitioner communities is that marketing as an organisational function has been relegated from the position of core strategy-making engine to marginalised sales support department in charge of T-shirts and promotion (as evidenced by the cultural web shown in Figure 5).

\section{From tactics to strategy}

To instigate a recovery in marketing and revitalise this key source of competitive power, marketers must act with deliberate and determined resolve. Firstly, they have to work hard to recapture the high ground the strategy domain. This, however, means reaching some kind of consensus about what marketing is (and is not). Enormous damage is done to the cause when the president of the Chartered Institute of Marketing declares: 'Marketing isn't a function. It is an attitude of mind. ${ }^{17}$ Many will wonder how an attitude of mind can be measured, researched, developed, protected, examined, etc, all of these being the avowed purpose of the professional body. Nonetheless, in one sense, of course, she is correct, because marketing as a function can never be effective in any organisation that does not put the customer at the core of its operations. Add to this the hundreds of different definitions of marketing to be found in books and papers on marketing, and the confusion is complete. A selection of 30 such definitions are to be found in McDonald, ${ }^{18}$ most of which involve doing things to customers.

Let us be unequivocal about marketing. Just like finance, or HR, or IT, it is a function: a specific business activity that fulfils a fundamental business purpose. Consider marketing in terms of what it actually entails. Marketing is a process for:

— defining markets

- quantifying the needs of the customer groups (segments) within these markets

- putting together the value propositions to meet these needs, communicating these value propositions to all those people in the organisation responsible for delivering them and getting their buy-in to their role

- playing an appropriate part in delivering these value propositions (usually only communications)

— monitoring the value actually delivered. 


\section{The cornerstone of corporate success is marketing}

For this process to be effective, organisations need to be consumer/ customer-driven. ${ }^{19}$

This consolidated summary of the marketing process is shown diagrammatically in Figure 7.

There is more than enough evidence (see, for example, Jenkins and McDonald ${ }^{20}$ ) to prove that the key determinants of corporate success correct market definition, market segmentation and market positioning are poorly understood by corporations. The map of the process in Figure 7 works to simplify what is a complex process into a series of manageable steps. It provides a practical framework for understanding and tackling the multitude of issues that comprise marketing, leading to sustainable competitive advantage.

Steps 1 and 2 are about strategy determination, while steps 3 and 4 are about tactical implementation and measurement. It is these latter two that have come to represent marketing as a function which is still principally seen as sales support and promotion.

The term 'Determine value proposition' has been used to make plain that here one is referring to the decision-making process of deciding what the offering to the customer is to be - what value the customer will receive and what value (typically the purchase price and ongoing revenues) the organisation will receive in return. The process of delivering this value, such as by making and delivering a physical product or by delivering a service, is covered by 'Deliver value proposition'.

It is well known that not all of these marketing activities will be under the control of the marketing department, whose role varies considerably

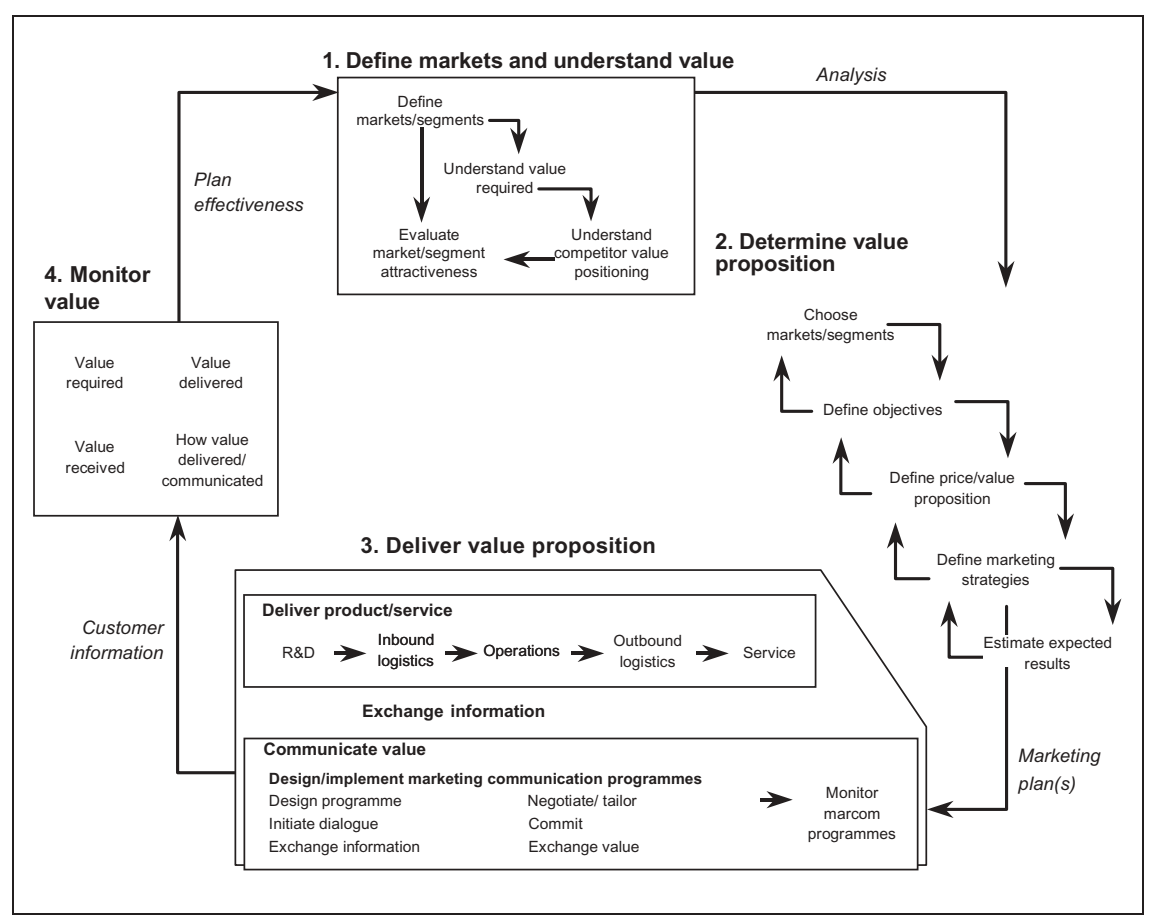

Figure 7: Summary of marketing map 


\section{An organisation's strategic choices will be constrained by its asset base}

between organisations. The marketing department should be in charge of the first two subprocesses, 'define markets and customer value' and 'determine value proposition', although even these need to involve numerous functions, albeit coordinated by specialist marketing personnel. Responsibility for delivering value is the shared domain of the whole company, however, requiring cross-functional expertise and collaboration. It will include, for example, product development, manufacturing, purchasing, sales promotion, direct mail, distribution, sales and customer service.

The marketing process is clearly cyclical, in that monitoring the value delivered will update the organisation's understanding of the value that is required by its customers. The cycle may be predominantly an annual one, with a marketing plan documenting the output from steps 1 and 2, but equally changes throughout the year may involve fast iterations around the cycle to respond to particular opportunities or problems.

The various choices made during this marketing process are constrained and informed not only by external factors in the marketing environment, but also by the organisation's asset base. Whereas an efficient new factory with much spare capacity might underpin a growth strategy in a particular market, a factory running at full capacity might consider whether price should be used to control demand, unless the potential demand warranted further capital investment. Choices may be influenced by physical assets and/or the less tangible but substantial value afforded by the organisation's people, brands, financial status and information technology. (For a detailed explanation of the marketing map, see McDonald. ${ }^{21}$ )

\section{Marketing's role in value creation}

The marketing map asserts marketing's central role in creating value in the marketplace. The overall purpose of strategic marketing, and its principle focus, is the identification and creation of sustainable competitive advantage. Figure 8 shows diagrammatically how sustainable competitive advantage can be achieved.

Managing the element of risk is, of course, key to strategic marketing. Figure 9 shows a typical array from any stock exchange of the relationship between risk and return, the diagonal line being the required rate of return.

Any firm on the diagonal line will normally be making industry average returns for its shareholders, or returns equal to the weighted average cost of capital (WACC). Firms making consistent returns greater then the WACC are creating shareholder wealth, known generally as shareholder value added, economic value added, positive net present value (NPV), superior profits, sustainable competitive advantage and so on.

As Doyle has pointed out, ${ }^{22}$ modern finance is based on four principles:

- cash flow (the basis of value)

- the true value of money

- the opportunity cost of capital (other investments of a similar risk) 


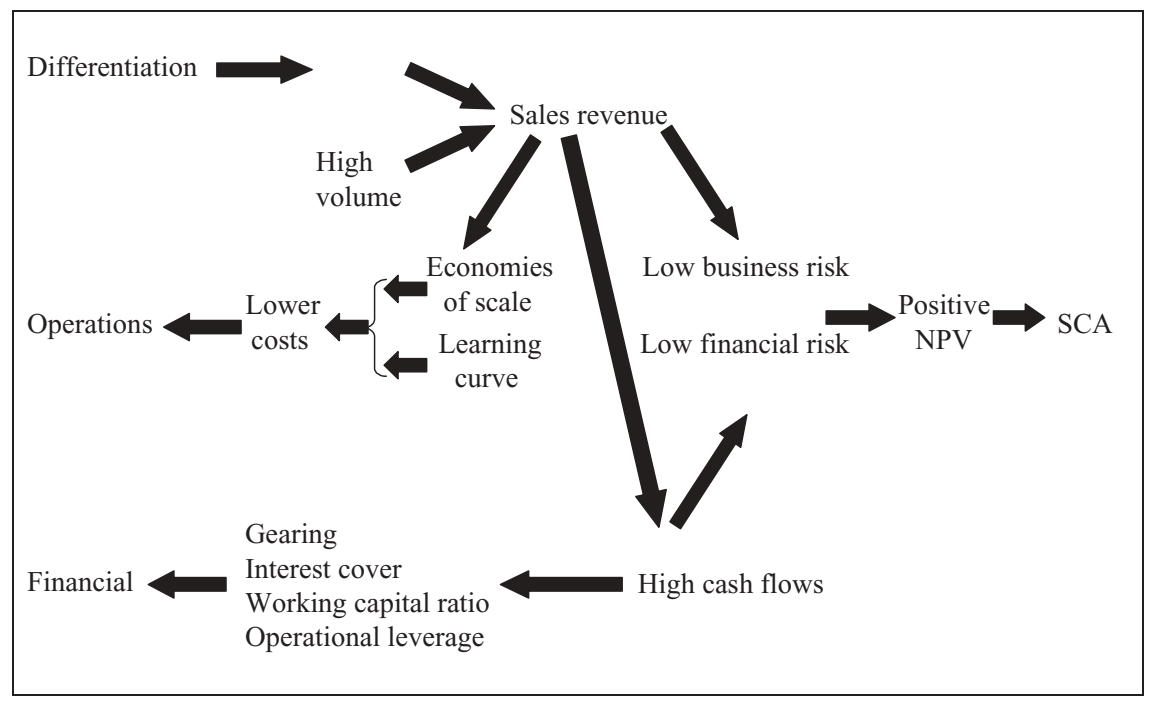

Figure 8: The route to sustainable competitive advantage (SCA)

\section{The whole organisation must focus its attention on customers}

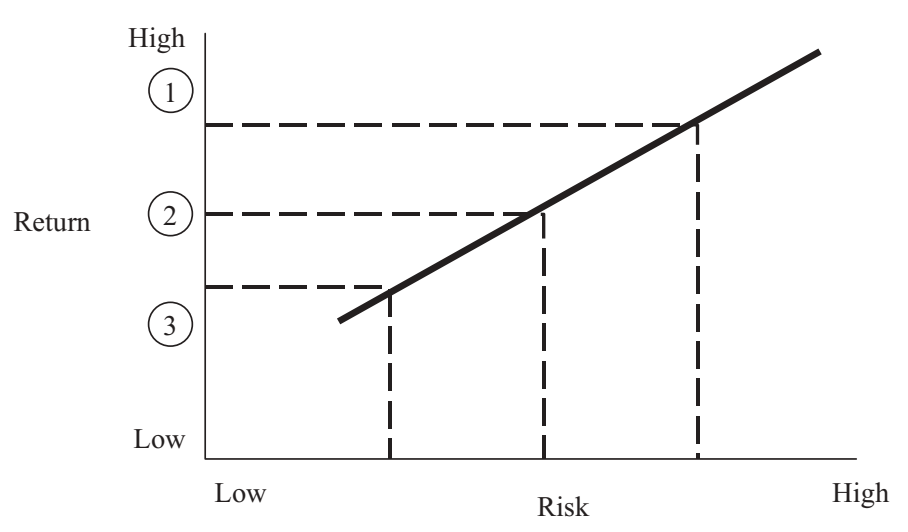

Figure 9: Financial risk and return

Source: Adapted from Sri Srikanthan, Cranfield School of Management

- the concept of NPV (the sum of the net cash flows discounted by the opportunity cost of capital).

Doyle also emphasised that, while accountants do not measure intangible assets, the discrepancy between market and book values shows that investors do. Hence, expenditures to develop marketing assets make sense if the sum of the discounted cash flow they generate is positive.

A little thought will indicate that every single corporate activity, whether it be R\&D, IT, purchasing or logistics, is ultimately reflected in the relative value put on a firm's offer by its customers. The marketing function, as defined in Figure 7 (particularly the strategic roles outlined in steps 1 and 2), is central to this attribution of value as every one of the 
four (or five, six or seven) Ps can only be improved by the whole organisation focusing its attention on its customers.

\section{Conclusion}

The main point of all this is that for marketing to survive, and indeed thrive, as the powerful function one knows it can be, some radical changes must take place. Realising marketing's full potential requires universal recognition of its acute strategic importance and commitment to the adoption of a sensible approach to its implementation. Failure to learn from experience can have very hard-hitting and long-lasting implications.

Marketing must find a way of escaping from the increasing proclivity of the academic community to creep further and further into the more esoteric groves of academe, talking about increasingly narrow issues in an increasingly impenetrable language to an increasingly restricted audience. Academics must address issues which are of concern to the real world and which are central to business success. They can, in doing this, be academic and rigorous, but they must then learn to translate their findings into actionable propositions.

The practical framework given here is an effort to steer away from the misguided and misrepresented notions of marketing, and towards a more realistic and relevant pursuit of marketing excellence. Marketing is long overdue for a reality check and it is high time the health of marketing was put at the forefront of change.

\section{Acknowledgment}

A version of this paper was first published in The Marketing Review, Vol. 3, No. 3, pp. 253-271 under the title 'Marketing: Priority case for a reality check'. (C) 2003 Westburn Publishers Ltd. Reprinted with permission from McDonald, M. (2003).

\section{References}

1. Wills, G. (1976) Business School Graffiti - A Decennial Transcript, MCB Books, Bradford.

2. Eliot, T. S. (1934) 'The Rock'.

3. Brady, J. and Davis, I. (1993) 'Marketing in transition: Marketing's mid-life crisis', McKinsey Quarterly, No. 2, pp. 17-28.

4. Peters, T. J. and Waterman, R. H. (1982) In Search of Excellence, Warner Books, New York.

5. Pascale, R. T. (1990) Managing on the Edge, Simon and Schuster, New York.

6. Davidson, H. (1998) Even More Offensive Marketing, Butterworth-Heinemann, Oxford.

7. Reichheld, F. F. and Sasser, W. E. Jr (1990) 'Zero definitions: Quality comes to service', Harvard Business Review, September-October, pp. 105-111.

8. Haigh, D. (2000) Brand Finance Report, Brand Finance, London; Davidson, H. (2001) The Committed Enterprise, Butterworth-Heinemann, Oxford.

9. Johnson, G. and Bailey, A. (1992) 'Managing strategic change: Strategy, culture and action', Long Range Planning, Vol. 25, No. 1, pp. 28-36.

10. Baker, S. (2000) 'Defining a marketing paradigm — The view of senior non-marketers', paper presented to the Academy of Marketing Conference, Derby University.

11. Greenley, G. (1994) 'Marketing planning in UK and US companies', Journal of Strategic Marketing, Vol. 2, No. 2, pp. 140-154.

12. Edwards, C. and Peppard, J. (1997) 'Operationalizing strategy through process', Long Range Planning, Vol. 30, No. 5, pp. 753-756. 
13. Fournier, S., Dobsche, S. and Mick, D. G. (1998) 'Preventing the premature death of relationship marketing', Harvard Business Review, January-February, pp. 42-50.

14. McDonald, M. (2000) 'Marketing, existential malpractice and an etherised discipline: A soteriological comment', Academy of Marketing Debate, University of Derby.

15. Wensley, R. (2000) 'The MSI priorities: A critical review on researching firm performance, customer experience and marketing', Journal of Marketing Management, Vol. 16, Nos 1-3, pp. 11-27.

16. McDonald, M. (2001) Open University Business School, critique of a new MBA Module on Postmodern Marketing.

17. Thompson, D. (2001) Keynote speech, Chartered Institute of Marketing Annual Fellows Dinner.

18. McDonald, M. (2002) Marketing Plans: How to Prepare Them; How to Use Them, ButterworthHeinemann, Oxford.

19. Ibid.

20. Jenkins, M. and McDonald, M. (1997) 'Market segmentation: Organisational archetypes and research agendas', European Journal of Marketing, Vol. 31, No. 1, pp. 17-32.

21. McDonald, ref. 17 above.

22. Doyle, P. (2000) 'How shareholder value analysis redefines marketing', Market Leader, Spring, pp. 16-25. 